\title{
Analysis of Summer Ozone Observations at a High Mountain Site in Central Italy (Campo Imperatore, $2388 \mathrm{~m}$ a.s.l.)
}

\author{
P. Cristofanelli, ${ }^{1,4}$ P. di Carlo, ${ }^{2,3}$ A. D’. Altorio, ${ }^{2}$ C. Dari Salisburgo, ${ }^{3}$ P. Tuccella \\ F. Biancofiore, ${ }^{3}$ P. Stocchi, ${ }^{3,4}$ G. P. Verza, ${ }^{4}$ T. C. Landi, ${ }^{1}$ A. Marinoni, ${ }^{1}$ F. Calzolari \\ R. Duchi, ${ }^{1}$ and Paolo Bonasoni ${ }^{1,4}$
}

\begin{abstract}
Tropospheric ozone $\left(\mathrm{O}_{3}\right)$ is an important atmospheric pollutant and climate forcer. The Mediterranean basin is a hot-spot region in terms of short-term $\mathrm{O}_{3}$ distribution, with frequent episodes of high tropospheric $\mathrm{O}_{3}$, especially during summer. To improve the characterisation of summer $\mathrm{O}_{3}$ variability in the Mediterranean area, during the period 6-27 August 2009 an experimental campaign was conducted at Campo Imperatore, $\mathrm{Mt}$ Portella (CMP), a high mountain site (2,388 $\mathrm{m}$ a.s.1.) located in the central Italian Apennines. As deduced from analysis of atmospheric circulation, the measurement site was significantly affected by air masses originating over the Mediterranean basin, which affected the measurement site for $32 \%$ of the time. Analysis of average values and diurnal and day-to-day variability revealed that $\mathrm{CMP} \mathrm{O}_{3}$ observations (average value $60.0 \pm 5.1 \mathrm{ppbv}$ ) were comparable with measurements at other European mountain stations, indicating a prevalent effect of meteorological conditions and atmospheric transport on the synoptic scale. In fact, only a small "reverse" diurnal variation typically characterises diurnal $\mathrm{O}_{3}$ variability because of local thermal wind circulation, which sporadically favours transport of air masses rich in $\mathrm{O}_{3}$ from the foothill regions. Statistical analysis of five-day back-trajectory ensembles indicates that synoptic-scale air-mass transport from the Mediterranean Sea usually results in decreasing $\mathrm{O}_{3}$ concentrations at CMP, whereas the highest hourly $\mathrm{O}_{3}$ values are mostly associated with air masses from central continental Europe, eastern Europe, and northern Italy. High $\mathrm{O}_{3}$ concentrations are also related to downward air-mass transport from higher altitudes. Comparison of in-situ $\mathrm{O}_{3}$ variability with tropospheric $\mathrm{O}_{3}$ satellite-based measurements reveals similar features of the two data sets. Together with the results from back-trajectory analysis, this indicates that CMP measurements might usefully improve characterisation of broad-scale $\mathrm{O}_{3}$ variability over the central Mediterranean basin.
\end{abstract}

1 Institute of Atmospheric Sciences and Climate, National Research Council, via Gobetti 101, 40129 Bologna, Italy. E-mail: p.cristofanelli@isac.cnr.it

2 Dipartimento di Fisica, Università degli studi di L'Aquila, L'Aquila, Italy.

3 Center of Excellence CETEMPS, Universita' degli studi di L'Aquila, Via Vetoio, Coppito, L'Aquila, Italy.

4 Comitato EV-K2-CNR, Via San Berardino 145, Bergamo, Italy.
Key words: Ozone, summer, Italy, pollution, mountain, air-mass back-trajectories.

\section{Introduction}

Tropospheric ozone $\left(\mathrm{O}_{3}\right)$ is one of the most important atmospheric gases involved in photochemical reactions, and is the most important factor determining the oxidation capacity of the troposphere and air quality (JACOBSON, 2002). Tropospheric $\mathrm{O}_{3}$ has, moreover, been recognised as the third most important greenhouse gas contributing to anthropogenic radiative forcing (FORSTER et al., 2007).

The Mediterranean basin is a hot-spot region in terms of short-term $\mathrm{O}_{3}$ distribution and related anthropogenic contributions (MonKs et al., 2009): surface $\mathrm{O}_{3}$ concentrations have doubled in the Mediterranean basin compared with pre-industrial ages (UNEP and WMO, 2011). Photochemical production and $\mathrm{O}_{3}$ build-up frequently occur in this region during warm weather (VAUTARD et al., 2005). In fact, the Mediterranean basin is a sensitive region for occurrence of high $\mathrm{O}_{3}$ levels, especially during summer, because of the favourable meteorological conditions (high solar radiation, high temperature, and light surface wind), high emission of anthropogenic and natural $\mathrm{O}_{3}$ precursors, and its role as a major crossroad for airmass transport (LELIEVELD et al., 2002; CRISTOFANELLI and BonASONI, 2009). In particular, as summarized by Lolis et al. (2008), anti-cyclonic conditions usually prevail over the Mediterranean basin during summer, for a variety of reasons:

1. the enhanced action of the sub-tropical anticyclone; 
2. the downward heat fluxes driven by the cooling of the lower atmosphere over the cool sea surface; and

3. the subsidence over the eastern Mediterranean associated with the Asian monsoon.

However, atmospheric blocking over central Europe combined with cut-off lows in the eastern Mediterranean and the Gibraltar region can have a non-negligible effect on atmospheric circulation (especially in June, August, and September).

As a result of the interaction between $\mathrm{O}_{3}$ sources and air-mass transport (both regional and long-range), and because of its variable chemical lifetime (from days to a month), complex spatial and temporal variations in tropospheric $\mathrm{O}_{3}$ can lead to inhomogeneous distribution of its radiative forcing (MiCKLEY et al., 2004) and non-linear effects on regional air quality (WEST et al., 2009). Thus, observation of $\mathrm{O}_{3}$ variability in different regions can contribute to furnishing a more complete picture of spatial and temporal $\mathrm{O}_{3}$ features. For these reasons, continuous baseline $\mathrm{O}_{3}$ monitoring is a crucial activity for improving characterization of the variability of atmospheric properties in the Mediterranean troposphere. In particular, because mountains are often characterised by large "areas of representativeness" and by "clean" conditions, such locations are often regarded as useful for studying the background conditions of the lower troposphere (Henne et al., 2008). Despite this, and because of the challenging environmental and logistic conditions involved in performing atmospheric observations in high mountain regions, in-situ observations of $\mathrm{O}_{3}$ (and other atmospheric compounds) are still sparse in the Mediterranean region-although high-altitude measurement sites are present along the northern border of the region (e.g. the Alpine and Carpathian regions, Pyrenees), only the global GAW-WMO station of Monte Cimone (CMN, 2165 m, northern Apennines, Italy) is operational inside the region (see, for instance, the World Data Center for Greenhouse, Gases, http://ds.data.jma.go.jp/gmd/wdcgg/). Since 1996, long-term $\mathrm{O}_{3}$ monitoring has been conducted continuously at this station. Cristofanelli and Bonasoni (2009) pointed out the importance of natural processes (e.g. stratosphere-to-troposphere transport, mineral dust transport) and anthropogenic sources (e.g. pollution transport) in determining $\mathrm{O}_{3}$ variability at high altitudes over the Mediterranean basin. Together with other $\mathrm{O}_{3}$ observations conducted in the Mediterranean basin and southern Europe in the past (Kouvarakis et al., 2002; Nolle et al., 2005; Ribas and Peñuelas, 2004; Di CARlo et al., 2007), the observations have clearly shown that the tropospheric seasonal cycle of background $\mathrm{O}_{3}$ is usually characterised by the presence of a broad spring-summer peak in this region. Thus, investigation of summer $\mathrm{O}_{3}$ variability is particularly important over the Mediterranean basin, considering that the region is frequently affected by episodes of peak $\mathrm{O}_{3}$ increases (Monks et al., 2009).

To contribute to filling this information gap, in the framework of the Station at High Altitude for Environmental Research (SHARE) project, continuous measurements of surface $\mathrm{O}_{3}$ and meteorological data were performed at a high mountain site in the central Italian Apennines (Campo Imperatore, Mt Portella). The measurements were also performed to verify the feasibility of installing a permanent monitoring station at this measurement site. Although technical problems limited the duration of the $\mathrm{O}_{3}$ measurements (from 6 to 27 August 2009), they nonetheless constitute a unique data-set of $\mathrm{O}_{3}$ observations at a high altitude site in central Italy, thus yielding the first direct information on summer $\mathrm{O}_{3}$ levels and variability.

The observed $\mathrm{O}_{3}$ concentrations were analysed as a function of local meteorological conditions and by means of three-dimensional back-trajectory simulations. Compared with previous investigations at other high mountain locations in Europe, because of its location at the centre of the Italian peninsula, CMP appears to be particularly suitable for investigating the effect of European pollution exported from continental Europe and the Italian peninsula across the Mediterranean Sea (Lelieveld et al., 2002; DunCAN and Bey, 2004; HeNNE et al., 2005) and for directly characterising possible inputs from air masses originating from the marine boundary layer or higher tropospheric altitudes. Finally, comparison with satellite observations of $\mathrm{O}_{3}$ was conducted for preliminary (even if partial) evaluation of the representativeness of CMP observations on the broader scale for the experimental campaign period. 


\section{Materials and Methods}

\subsection{Site Description and Measurements}

Campo Imperatore (CMP) is the largest plateau of the Italian Apennine ridge, lying adjacent to the highest Apennine peak (Corno Grande, 2,912 m a.s.1.) and to Calderone, Europe's southernmost glacier (Fig. 1). The plateau's altitude ranges from 1,500 to $1,900 \mathrm{~m}$ and covers about $80 \mathrm{~km}^{2}$, with almost no vegetation except for thin patchy coverage of grass. The measurement site was close to the top of one of the peaks surrounding the CMP plateau, called Mt Portella (42.47 N; $13.55 \mathrm{E}$; 2,388 m a.s.1.). The site has a free horizon with no local pollution sources: the nearest village (Assergi, 500 inhabitants) is approximately $6 \mathrm{~km}$ away and approximately $1,000 \mathrm{~m}$ a.s.l. The nearest town is L'Aquila, with approximately 60,000 residents, which is located approximately $15.6 \mathrm{~km}$ from the observation site at approximately $720 \mathrm{~m}$ a.s.l., whereas Rome, with a population of approximately 3 million, is over $100 \mathrm{~km}$ from CMP.

At CMP, surface $\mathrm{O}_{3}$ was measured, by use of a Dasibi 1108 UV-absorption analyser, from 6 to 27 August 2009. Zero checks were automatically performed every $24 \mathrm{~h}$ and the instrument was calibrated before and after the experimental campaign. Following KLAUSEN et al. (2003), the combined uncertainty on the 1-min $\mathrm{O}_{3}$ measurements was less than \pm 2 ppbv in the $1-100$ ppbv range. The $\mathrm{O}_{3}$ concentrations reported in this work refer to STP conditions $\left(1,013 \mathrm{hPa}\right.$ and $\left.0{ }^{\circ} \mathrm{C}\right)$, and time is expressed as local time (UTC +1$)$. Meteorological observations (air temperature, relative humidity, wind speed and direction) were recorded on a 1-min basis by use of an automatic weather station (Lastem LSI).

\subsection{Air-Mass Back-Trajectory Calculations}

To evaluate both the origin and different paths of the air masses reaching CMP, 120-h 3D backtrajectories were calculated with the HYSPLIT model (DraXler and Hess, 1998). The model calculations were based on the GDAS meteorological field produced by NCEP with a horizontal resolution of $1^{\circ} \times 1^{\circ}$. For every point along the trajectory (time resolution $1 \mathrm{~h}$ ), the model provided the geographic location and altitude (or pressure level) of the air parcel. Sub-grid scale processes, for example convection and turbulent diffusion, are not represented by HYSPLIT back-trajectories. To compensate partially for these uncertainties, every $6 \mathrm{~h}$ starting from 6 August at 00:00 UTC, we calculated an ensemble of seven back-trajectories ending at the CMP site, at $\pm 0.5^{\circ}$ latitude/longitude and $\pm 250 \mathrm{~m}$ altitude.

\subsection{TES Satellite Measurements}

For the purpose of partially assessing the representativeness of CMP measurements of regional tropospheric $\mathrm{O}_{3}$ variability, we compared the in-situ CMP $\mathrm{O}_{3}$ values with tropospheric $\mathrm{O}_{3}$ data obtained by the Tropospheric Emission Spectrometer (TES) on board NASA satellite Aura. TES is an infrared, high spectral resolution Fourier transform spectrometer operating in nadir mode, with an actual nadir footprint of $\sim 5 \mathrm{~km} \times 8 \mathrm{~km}$, a spatial resolution of $2^{\circ}$ in latitude $/ 4^{\circ}$ in longitude and two-day temporal resolution. As shown by WORDEN et al. (2007) and NASSAR et al. (2008), TES can detect relative variations in the coarse vertical structure of tropospheric $\mathrm{O}_{3}$ and large-scale features of $\mathrm{O}_{3}$ spatial distribution. Here, we consider TES daily level 3 data, which are obtained by applying Delaunay triangulations on a latitude/longitude plane, followed by $2 \mathrm{D}$ interpolations for a fixed TES pressure level. The TES overpass time is approximately 13:30 $\mathrm{UTC}+1$. However, to avoid any effect of midday up-slope flow, only CMP $\mathrm{O}_{3}$ measurements from 00:00 to 05:00 UTC+1 were used. This provided more representative information on the free troposphere and, thus, on larger-scale $\mathrm{O}_{3}$ variability.

\section{Results}

\subsection{Meteorological Observations and Back- Trajectory Ensembles}

During the experimental campaign the average air temperature was $11.4 \pm 1.6^{\circ} \mathrm{C}$ and the average $\mathrm{RH}$ $81 \pm 16 \%$. Breezes were gentle (average values $4.6 \pm 2.5 \mathrm{~m} \mathrm{~s}^{-1}$ ), with high occurrence of northerly (frequency $40 \%$ ) and north-easterly (36\%) wind 


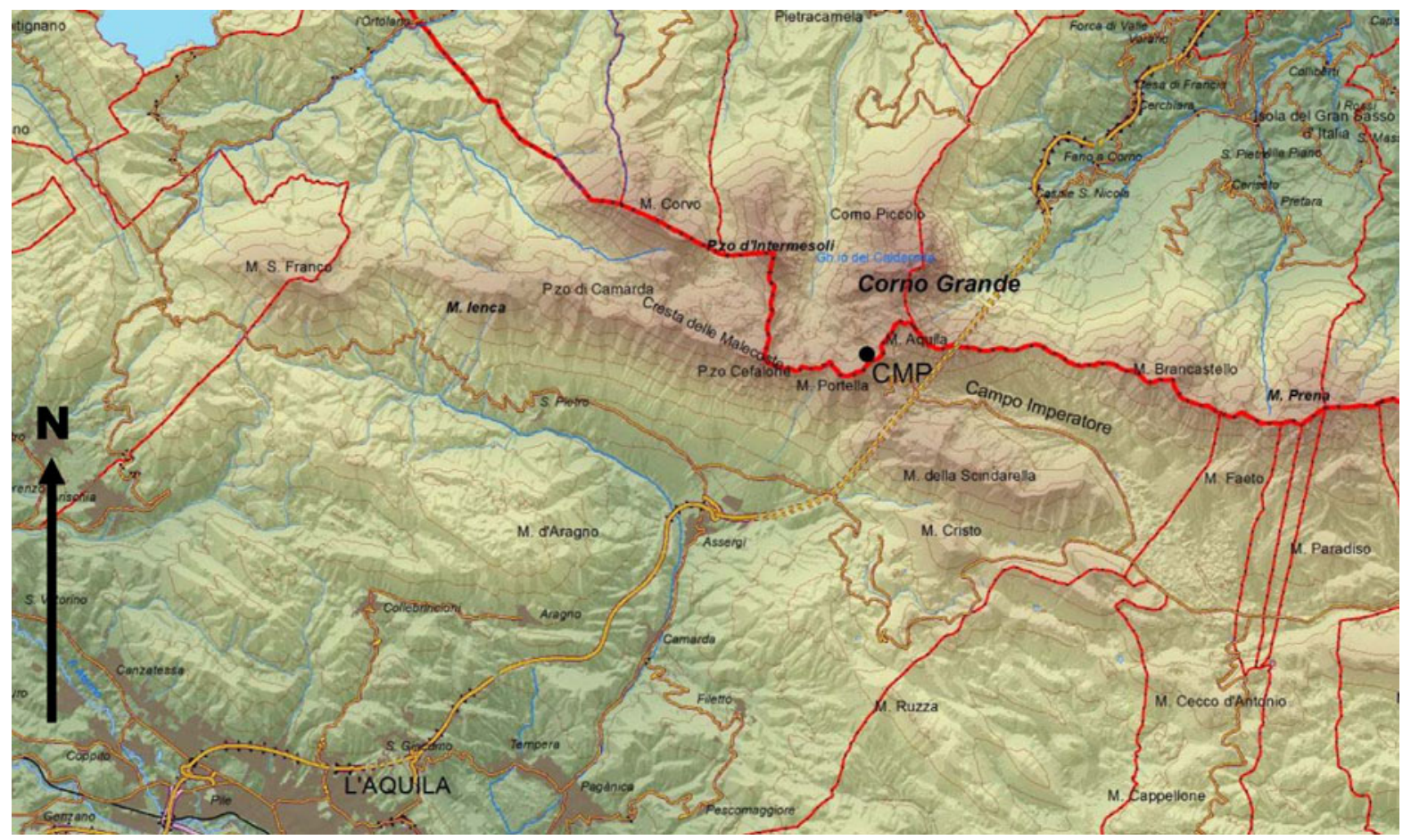

Figure 1

Region topography with CMP location

direction (WD), and secondary contributions from the south-west (7\%), west ( $8 \%$ ), and north-west $(6 \%)$.

To obtain a general visual impression of the air-mass flows characterising the CMP region for the experimental campaign, for each ensemble we calculated the field concentrations of the back-trajectory ending exactly at the CMP location (Fig. 2). To reveal the transport paths for "peripheral" regions at a distance from the measurement site, a logarithmic scale was adopted. Moreover, back-trajectory starting points are also reported to provide an indication of the spatial origin of the air masses reaching CMP. This elaboration clearly shows that during the period analysed CMP was affected by very different atmospheric transport patterns, with air masses originating (at $-120 \mathrm{~h}$ ) over different European continental regions, and over the Mediterranean Sea and Atlantic Ocean.

\subsection{Tropospheric $\mathrm{O}_{3}$ Behaviour}

The time series of 30-min averaged $\mathrm{O}_{3}$ data for CMP are reported in Fig. 3, and Table 1 shows the statistical overview for $\mathrm{O}_{3}$ observations. During the period considered, the average $\mathrm{O}_{3}$ value was $60.0 \pm 5.1 \mathrm{ppb}( \pm 1 \sigma, \mathrm{N}: 1010 ; 1 \mathrm{ppb}$ corresponds approximately to $1 \mu \mathrm{g} \mathrm{m}^{-3}$ ). Even considering the relatively short observation period, this value is comparable with typical summertime $\mathrm{O}_{3}$ levels (within the 50-64 ppb range) reported by CHEvALIER et al. (2007) and GHeusi et al. (2011) for continental European mountain stations from 1,860 to $3,580 \mathrm{~m}$ a.s.l. Figure 4 reports the average $\mathrm{CMP} \mathrm{O}_{3}$ values in comparison with the average summertime $\mathrm{O}_{3}$ levels (reference period 2001-2008) reported by GHEUsI et al. (2011) for the mountain stations of Put du Dôme (PUY, $1465 \mathrm{~m}$ asl, Massif Central, France), Pic du Midi (PDM, 2,875 m, Pyrenees, France), Zugspitze (ZUG, 2,950 m, central Alps, Germany), Jungfraujoch JUN (3,580 m, western Alps, Switzerland), and $\mathrm{CMN}$. In particular, the $\mathrm{O}_{3}$ mean level at CMP during the campaign was not very different from the climatological values observed at $\mathrm{CMN}$ (-3.8 ppb), ZUG (+3.3 ppb), and JUN (+1.2 ppb), as shown in Fig. 4. Even if caution is required in commenting on short-term measurements, this suggests that $\mathrm{O}_{3}$ levels observed at CMP in August 2009 


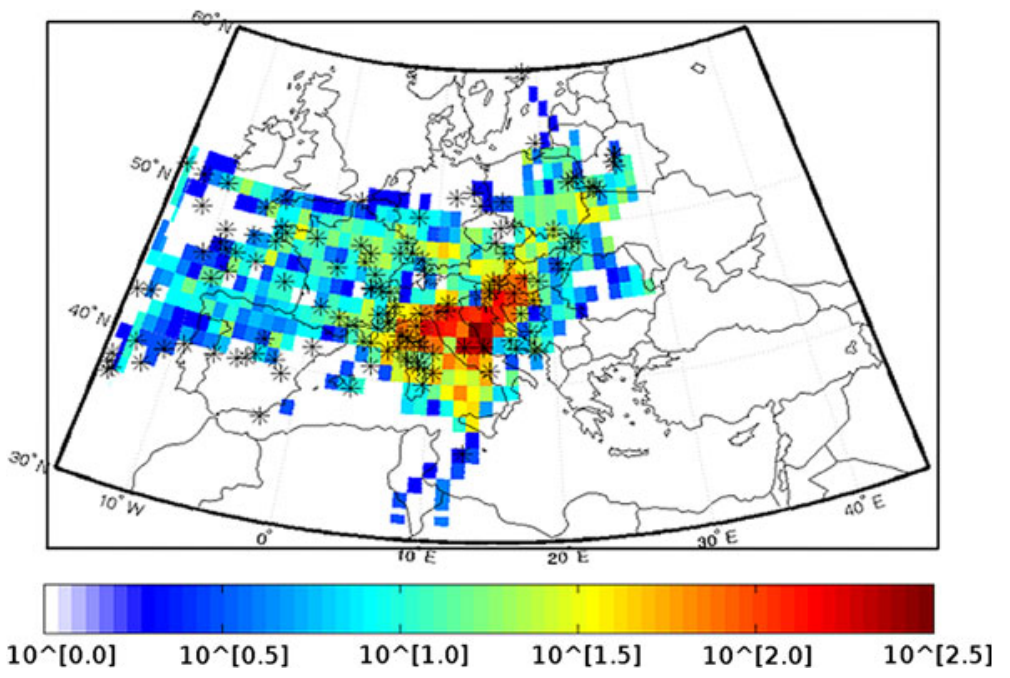

Figure 2

Concentration field for HYSPLIT with the number of back-trajectory points. Asterisks indicate the back-trajectory origins at $120 \mathrm{~h}$

can be regarded as representative of those at highaltitude sites in the Mediterranean basin. In fact, as shown by CHEvalier et al. (2007) and TARASOva et al. (2007), summer ozone levels generally increase with altitude, and moving from northern to southern latitudes in Europe. The trend is particularly evident for the four stations JUN, ZUG, CMN, and CMP, the two French stations (PMD and PUY) having rather different $\mathrm{O}_{3}$ values from other stations at the same altitudes or longitudes. Further analyses are needed to clarify this point (which is not within the scope of this paper). Nonetheless, we suggest that for PUY the difference can be explained by the rather low altitude of the measurement site (possibly more affected by air-masses from the atmospheric boundary layer, ABL) whereas for PMD it could be related to the frequent exposure to oceanic air masses, as suggested by GHeusi et al. (2011).

To investigate possible sources of $\mathrm{O}_{3}$ variability at $\mathrm{CMP}, \mathrm{O}_{3}$ standard deviations were calculated on the basis of hourly and daily averages $(\sigma 5.0$ and $3.3 \mathrm{ppb}$, respectively). The CMP hourly variability is in the bottom range of the values presented by CHEvalieR et al. (2007) for European mountain stations, thus indicating a rather limited effect of diurnal scale processes (e.g. photochemical production, "thermal" transport of high $\mathrm{O}_{3}$ concentrations). However, the ratio of daily/hourly standard deviations (69\%) indicated that diurnal variability is very important in determining the total $\mathrm{O}_{3}$ variability at CMP. For this reason both diurnal and day-to-day synopticscale $\mathrm{O}_{3}$ variability are examined below.

\subsection{1 $\mathrm{O}_{3}$ Diurnal Variations}

For the purpose of investigating diurnal processes affecting $\mathrm{O}_{3}$ variability at $\mathrm{CMP}, \mathrm{O}_{3}$ and meteorological data diurnal cycles were analysed (Fig. 5). Several studies (PRÈvôt et al., 2000; CARNUTH et al., 2002; Henne et al., 2005) have demonstrated the significant effect of the thermal wind system in redistributing $\mathrm{O}_{3}$ within mountain valleys and injecting it into the free troposphere. At CMP, specific humidity $(\mathrm{SH})$ was higher during the central part of the day than at night $(+4.0 \mathrm{~g} / \mathrm{kg})$, indicating that $\mathrm{ABL}$ air masses, richer in moisture, affected the measurement site (Zellweger et al. 2000; Henne et al. 2005). The importance of mountain slope winds (for a detailed definition, see GHeusi et al., 2011) is consistent with the diurnal pattern of WD at CMP. In fact, although a northerly wind mainly affected the measurement site at night (probably associated with downslope mountain winds from Corno Grande; Fig. 1), during the day the site was affected by southerly and westerly WD, indicating the occurrence of upslope winds from Mt Portella's south and 

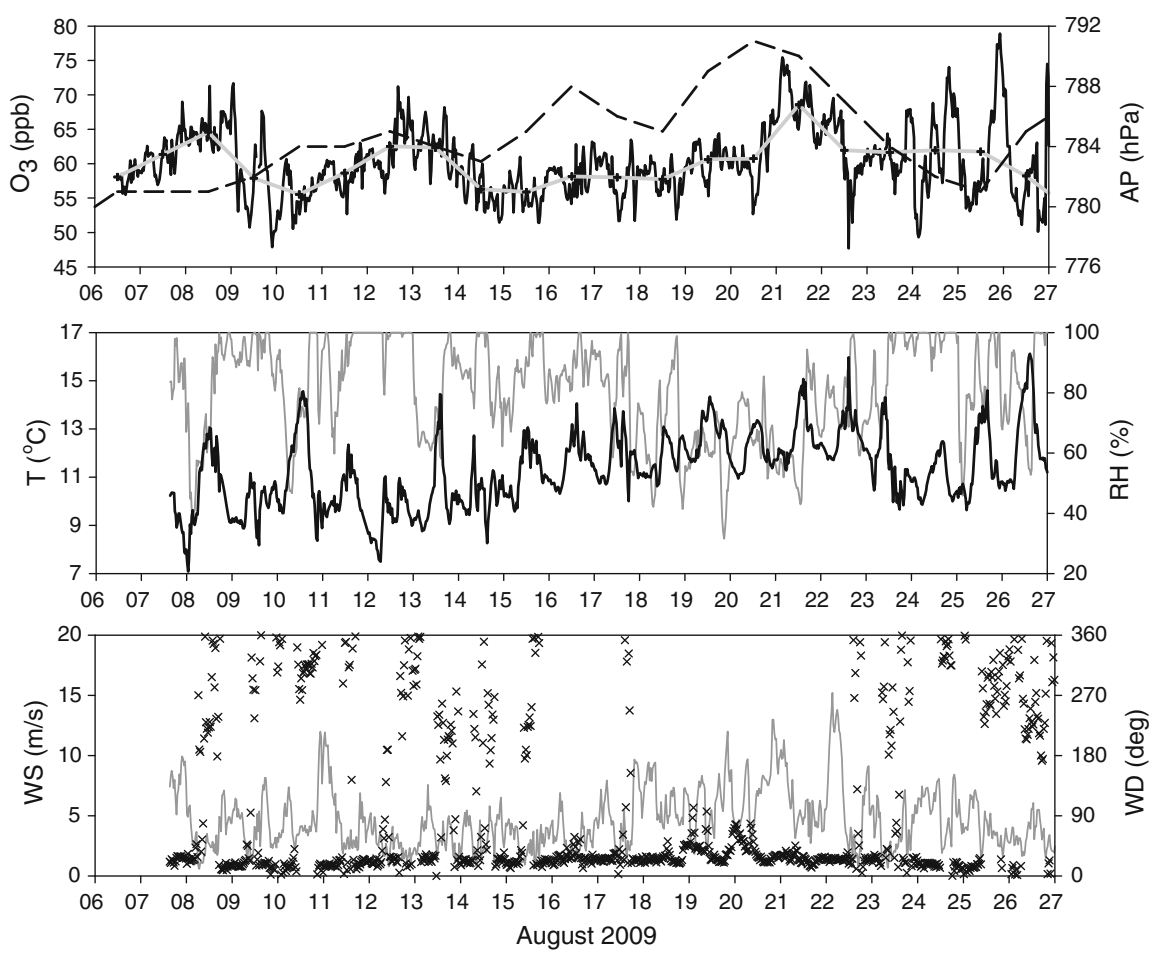

Figure 3

Upper plate time series of 30-min and daily average $\mathrm{O}_{3}$ values (black and grey continuous lines), and daily average atmospheric pressure $(A P)$. Middle plate time series of air-temperature (black line, $T$ ) and relative humidity (grey line, $R H)$. Bottom plate time series of wind speed (grey line, WS) and wind direction (crosses, WD)

Table 1

Basic statistical data for $\mathrm{O}_{3}$ (expressed in ppb) at CMP, during the period 6-27 August 2009, as a function of local wind direction

\begin{tabular}{|c|c|c|c|c|c|c|c|c|}
\hline Data & Minimum & 25 th percentile & Median & Average & 75th percentile & Maximum & St. dev. pop ${ }^{a}$ & Number of data \\
\hline All data & 46.0 & 56.6 & 59.4 & 60.0 & 62.9 & 78.9 & 5.0 & 1,018 \\
\hline $\mathrm{N}$ & 47.7 & 56.6 & 59.2 & 59.8 & 62.2 & 74.0 & 4.9 & 409 \\
\hline NE & 46.7 & 57.6 & 60.1 & 60.6 & 63.5 & 75.4 & 4.7 & 369 \\
\hline $\mathrm{E}$ & 50.8 & 58.9 & 60.1 & 59.6 & 60.6 & 66.6 & 2.9 & 20 \\
\hline SE & 51.4 & 57.6 & 59.6 & 59.4 & 60.8 & 66.3 & 4.1 & 8 \\
\hline $\mathrm{S}$ & 46.0 & 53.0 & 57.5 & 56.8 & 61.9 & 68.2 & 5.8 & 25 \\
\hline SW & 48.7 & 55.5 & 58.5 & 58.8 & 62.2 & 71.3 & 4.7 & 70 \\
\hline $\mathrm{W}$ & 52.1 & 55.4 & 59.5 & 60.9 & 64.1 & 78.9 & 6.9 & 46 \\
\hline NW & 50.4 & 55.1 & 57.6 & 59.9 & 64.8 & 77.3 & 6.6 & 63 \\
\hline
\end{tabular}

${ }^{\text {a }}$ Standard deviation of the population

west-facing slopes. Furthermore, wind speed was minimal during the daytime, as expected for a mountain peak site (GHeusi et al., 2011).

Analysis of average hourly $\mathrm{O}_{3}$ values revealed a small "reverse" $\mathrm{O}_{3}$ diurnal cycle (average amplitude $5.0 \mathrm{ppb}$ ). In particular, lower average $\mathrm{O}_{3}$ values were observed during daytime and higher concentrations characterised nighttime observations. Such behaviour is similar to that at other high-altitude mountain sites: BONASONI et al. (2000) and Fischer et al. (2003) reported similar findings at Mt Cimone $(2,165 \mathrm{~m}$ a.s.l., northern Apennines). Such behaviour can be associated with transport of air masses depleted in $\mathrm{O}_{3}$ from the ABL during the morning hours (possibly affected by dry deposition) and with the presence of air masses richer in $\mathrm{O}_{3}$ and more representative of 

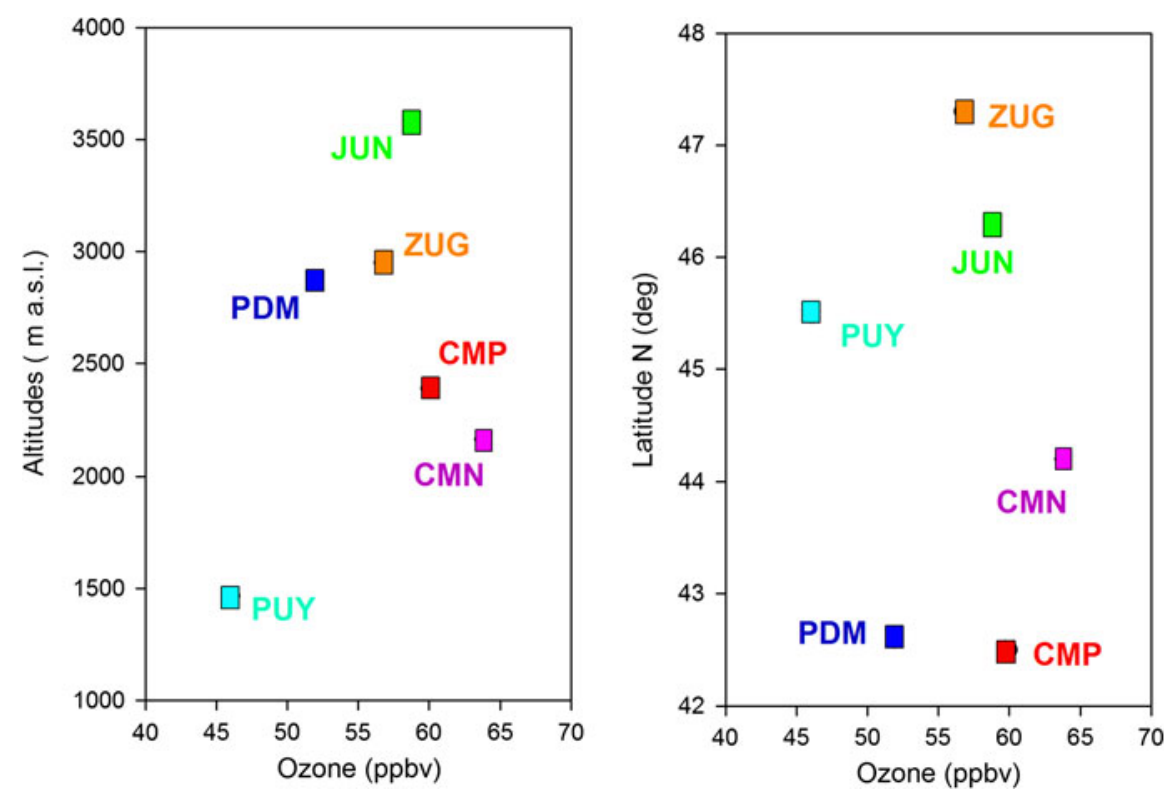

Figure 4

Summertime mean $\mathrm{O}_{3}$ values at CMP during the experimental campaign in comparison with the climatological values (period 2001-2008) reported by GHeusi et al. (2011) for five European mountain stations: Jungfraujoch (JFJ), Zugspitze (ZUG), Pic du Midi (PDM), Monte

Cimone $(C M N)$, Puy de Dôme $(P U Y)$. On the left (right): the y-axis reports the altitudes (latitudes) of the measurement sites

higher tropospheric layers during the night. Actually, by selecting $\mathrm{O}_{3}$ levels as a function of wind sector (Table 1), the lowest average $\mathrm{O}_{3}$ concentrations $(56.8 \pm 2.3 \mathrm{ppb})$ were observed in association with southerly winds, probably related to the upward transport of air masses from the lower troposphere by thermal circulation. Similar behaviour is also discernible in the upper and lower percentiles of the hourly $\mathrm{O}_{3}$ distributions, even if an increase in the highest percentiles (75th and 90th) around midday and late afternoon (16:00-17:00) suggests the possibility that polluted air masses richer in photochemical $\mathrm{O}_{3}$ could occasionally affect the site in association with upslope breezes. In particular, high $\mathrm{O}_{3}$ concentrations (mostly exceeding $70 \mathrm{ppb}$ ) were observed in the afternoon and evening, coinciding with diurnal wind rotation to the south and west under light breeze circulation (e.g. 9, 13, and 25 August). The probable source of these polluted air masses is the L'Aquila urban area. In fact, on the basis of the WS observed at CMP during midday-afternoon (ranging from 3 to $8 \mathrm{~m} / \mathrm{s}$ ) and assuming the value to be representative for the region near the measurement site, a transport distance of approximately $12-32 \mathrm{~km}$ in $1 \mathrm{~h}$ can be estimated. This distance encompassed L'Aquila, thus supporting the hypothesis that emissions from this urban area can affect CMP. With the objective of estimating $\mathrm{O}_{3}$ production within the $\mathrm{ABL}$ air masses ascending to CMP, we considered surface $\mathrm{O}_{3}$ data recorded at a sub-urban air-quality station in L'Aquila (AQU) on 9, 13, and 25 August. Then, we compared the highest $\mathrm{O}_{3}$ hourly values at AQU (recorded from 13:00 to 16:00) with those recorded at CMP (recorded from 16:00 to 24:00) during these days. $\mathrm{O}_{3}$ production rates ranging from 5 to $14 \mathrm{ppb} / \mathrm{h}$ along the transport path were deduced by calculating the ratio between the excess $\mathrm{O}_{3}$ observed at CMP and the time delay between the appearance of $\mathrm{O}_{3}$ peaks at AQU and CMP.

As shown by the analysis of the 10th and 25th percentiles, low $\mathrm{O}_{3}$ values can also be observed at CMP in the late evening. The meteorological observations (Fig. 4) suggested that this is the time of the transition between upward and downward flows at the site. Thus, the observed $\mathrm{O}_{3}$ depletion can be tentatively related to the recirculation of air masses relatively poor in $\mathrm{O}_{3}$ because of dry deposition or titration by $\mathrm{NO}$ in residual ABL air masses. 

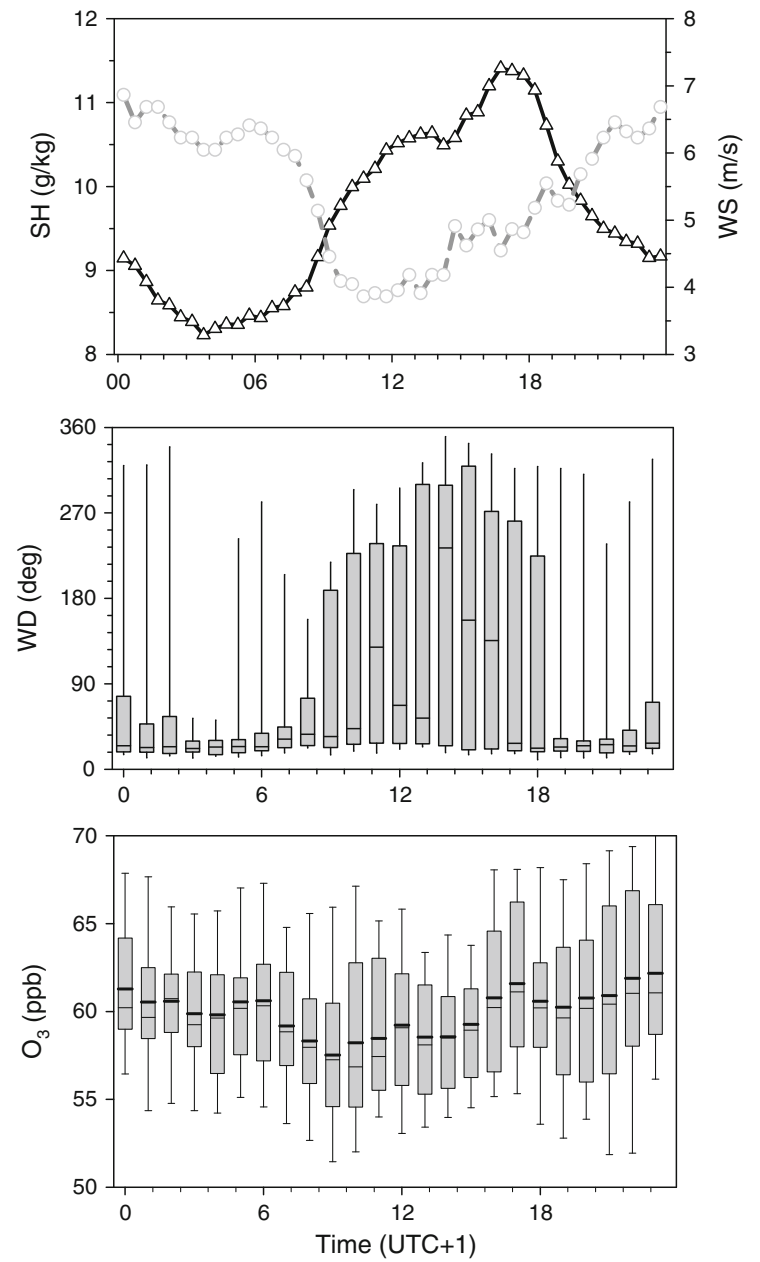

Figure 5

Diurnal variations of specific humidity (black line, $\mathrm{SH}$ ) and wind speed (gray line, WS) average hourly values (upper plate), local wind direction (middle plate) and surface $\mathrm{O}_{3}$ (bottom plate). For $\mathrm{WD}$ and $\mathrm{O}_{3}$ the box-and-whisker plots denote the 10th, 25th, 50th, 75th, and 90th percentiles of the hourly distributions. In the bottom plate, the bold line denotes mean hourly $\mathrm{O}_{3}$ values

\subsubsection{Effect of Synoptic-Scale Atmospheric Circulation}

To study the synoptic-scale variations (i.e. over a few days) affecting $\mathrm{O}_{3}$ at $\mathrm{CMP}$, the behaviour of daily mean values was analysed (Fig. 3). During the experimental campaign, three "episodes" of $\mathrm{O}_{3}$ increase were observed: 8, 12-13, and 21-22 August. In addition, high hourly $\mathrm{O}_{3}$ values were observed on 24 August, when northerly winds prevailed all day long at CMP, suggesting synoptically driven circulation at the measurement site. We considered the results of HYSPLIT back-trajectory analysis and the meteorological observations at CMP to interpret these episodes.

- On 8 August 2009, daily $\mathrm{O}_{3}$ values of 65 ppb were recorded at CMP. Back-trajectory analyses showed the measurement site was affected by air masses which originated over central and eastern Europe. In particular, during their transport toward central Italy and CMP (Fig. 6a), these air masses travelled at relatively low altitudes (at pressures greater than $800 \mathrm{hPa}$ ) over Romania, Bulgaria, and the Czech Republic. As reported by the European Environment Agency (EEA 2010), on 1-3 August 2009, exceedances of the $\mathrm{O}_{3}$ information threshold $\left(180 \mu \mathrm{g} \mathrm{m}^{-3}\right.$ or $\left.90 \mathrm{ppb}\right)$ were recorded in these countries. Thus, despite a possible contribution related to the transport of polluted air masses from the regional ABL by local "thermal" winds, the possibility that the high $\mathrm{O}_{3}$ values at CMP might be because of photochemical $\mathrm{O}_{3}$ production over west and central Europe cannot be ruled out.

- On 12-13 August 2009, average daily values of $63 \mathrm{ppb}$ were observed with hourly peak values of 71 and $68 \mathrm{ppb}$. On 12 August, surface $\mathrm{O}_{3}$ started to increase from around 12:00 (55 ppb) to 16:00-18:00 (70 ppb). During this period, north-northwesterly winds prevailed, with high RH (100\%). On 13 August at 00:00, RH started to decrease with relatively dry conditions (RH approx. $58 \%$, substantially lower than the average for the experimental campaign) being observed until 16:00. Until 12:00, relatively high $\mathrm{O}_{3}$ values were observed (up $67 \mathrm{ppb}$ ), with northerly winds. Southerly winds started to develop only from 12:00, thus with a time delay of approximately $5 \mathrm{~h}$ compared with the typical conditions (Fig. 5). From midday of 12 August, the atmospheric circulation was characterised by airmasses originating over central Europe at relatively low pressures $(900 \mathrm{hPa})$, whereas starting from 13 August air masses from the middle troposphere (at pressures below $600 \mathrm{hPa}$ ) of the western Europe/ Atlantic Ocean were identified by HYSPLIT (Fig. 6b). Thus it is likely that anthropogenic contributions from central Europe and air masses from the "free troposphere" both contributed to determining the high $\mathrm{O}_{3}$ levels. As reported in previous work 

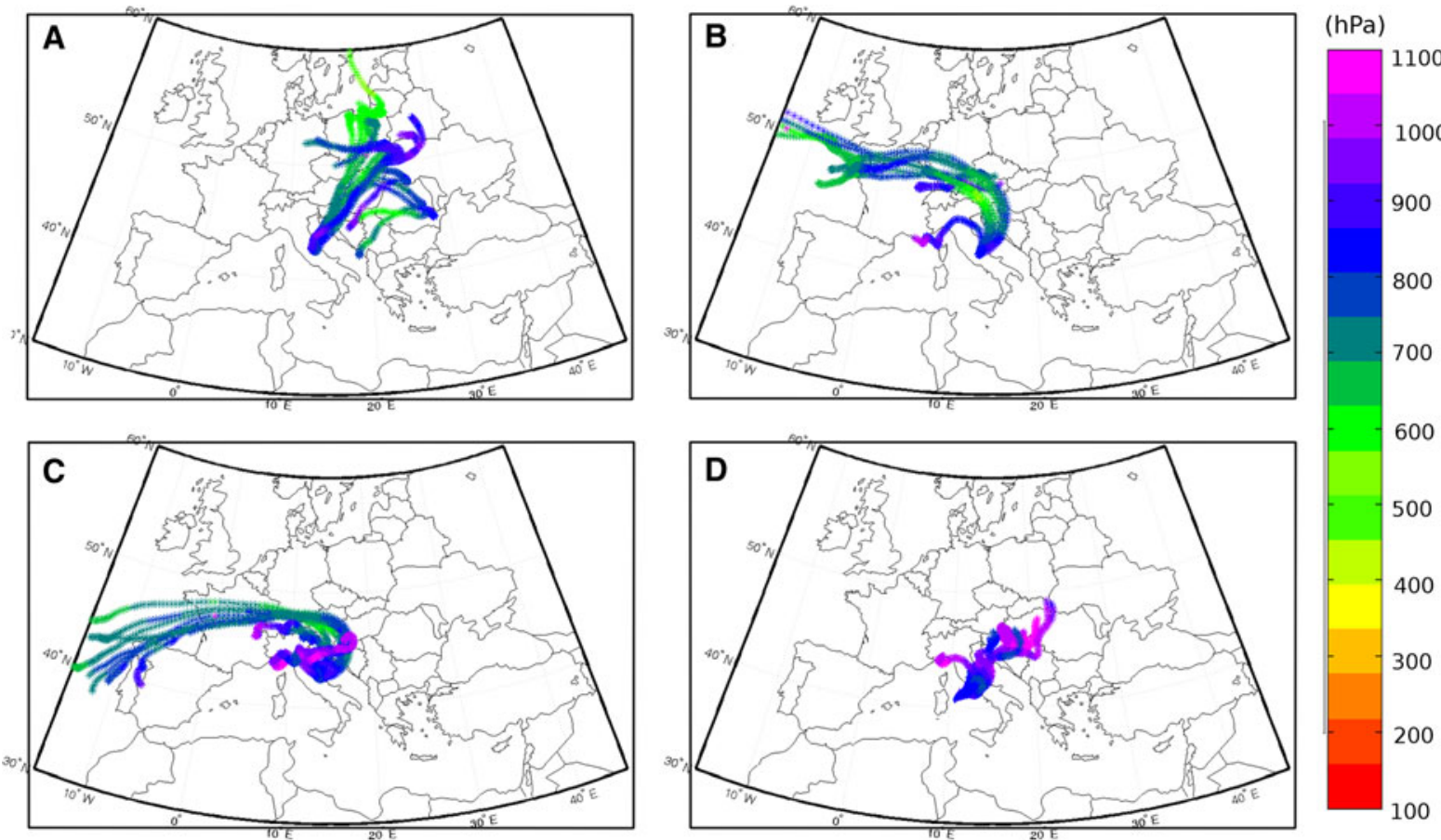

Figure 6

HYSPLIT five-day back-trajectories ending at the CMP location on 8 August 2009 (a), 12-13 August 2009 (b), $20-21$ August 2009 (c), and 24 August 2009 (d). The coloured scale indicates the pressure level of the back-trajectory points

(HeNNe et al., 2005), summer dry convection and ABL growth over the European continent can favour the transport of polluted air masses to altitudes that would usually be in the free troposphere. Thus, the possibility that the $\mathrm{O}_{3}$ increase at CMP was because of pollution enrichment of air masses travelling at relatively high altitudes over west-central Europe cannot be excluded.

- On 20-21 August, the highest $\mathrm{O}_{3}$ concentrations of the experimental campaign were observed. In particular, on 21 August, a daily mean concentration of $68 \mathrm{ppb}$ was recorded (peak hourly value $73 \mathrm{ppb}$ ). During this period, relatively low $\mathrm{RH}$ (average value $60 \%$ ) with moderate to high northerly winds were continuously observed at the measurement site, possibly indicating a major effect of synoptic-scale circulation. In this context, the HYSPLIT back-trajectory analyses (Fig. 6c) showed that two different classes of atmospheric circulation possibly affected CMP: (1) westerly air masses originating from the western Europe/Atlantic Ocean "free troposphere" (from 20 August 00:00 to 21 August 9:00); (2) air masses which originated in and travelled over the $\mathrm{ABL}$ (pressure greater than 1,000 hPa) of the Balkan peninsula (from 21 August 12:00 to 22 August). These circulations were associated with the occurrence of a high pressure system over central Italy, as reflected by the increase in the atmospheric pressure at CMP (Fig. 3). The "free tropospheric" air masses were concomitant with the highest $\mathrm{O}_{3}$ peak on the night between 20 and 21 August, and the eastern Europe air masses possibly contributed to the $\mathrm{O}_{3}$ peak during the afternoon and evening of 21 August. Such evidence suggests that air masses enriched in $\mathrm{O}_{3}$ from the free troposphere and continental Europe ABL could both have contributed to determining the high $\mathrm{O}_{3}$ values at CMP.

- High hourly $\mathrm{O}_{3}$ values were also recorded at CMP on 24 August (up to $74 \mathrm{ppbv}$ at 19:00). In this case, the occurrence of weak to moderate (up to $8 \mathrm{~m} \mathrm{~s}^{-1}$ ) northerly winds suggests that direct transport by upslope thermal winds was unlikely. Nevertheless, the high RH values (up to $100 \%$ ) indicated possible contributions by air masses enriched in water vapour from the lower troposphere. This possibility was 
supported by the HYSPLIT analyses (Fig. 6d), which were indicative of substantial air-mass recirculation over central Italy and eastern Europe at pressures greater than $1,000 \mathrm{hPa}$, suggesting that uplift of polluted air masses from the ABL of these regions could contribute to the $\mathrm{O}_{3}$ increase at CMP.

\subsubsection{Analysis of Surface $\mathrm{O}_{3}$ as a Function of Back-Trajectory Clusters}

As indicated by the previous analysis, synoptic-scale transport processes could have contributed to determining $\mathrm{O}_{3}$ variability at CMP during the investigated period. To capture systematically the main synopticscale flows occurring at the measurement site, non hierarchical cluster analysis (DoRLING et al., 1992) was applied to the HYSPLIT back-trajectory ensembles. To retrieve the largest amount of information, the clustering was applied to all single elements of the back-trajectory ensembles. At each step of the agglomeration process, the appropriate number of clusters was determined by analysing the variations of specific statistical data, i.e. total trajectory dispersion and total root mean square deviation, to define the optimum number of clusters. The analysis led to identification of five main circulation patterns affecting CMP during the experimental campaign (Fig. 7):

1. Continental Europe (CE): air masses slowly passing or recirculating over central-eastern Europe and central-northern Italy, mostly with mixing below 2,000 $\mathrm{m}$ a.g.l. (frequency of occurrence $23.0 \%$; main pollution source areas: north Italy, south Germany, the "Black Triangle" ${ }^{1}$ );

2. Western Europe (WE): air masses experiencing anti-cyclonic subsidence, and from western Europe and the Atlantic Ocean, travelling to continental Europe at altitudes above 2,000 m a.g.l. (frequency of occurrence $24.2 \%$ );

3. Atlantic Ocean (AO): air masses with five-day origin over the Atlantic Ocean, travelling mainly at altitudes above $3,000 \mathrm{~m}$ a.s.l. and never descending lower than the CMP altitude (8.4\%);

1 The "Black Triangle" is defined as the area between Germany's southern Saxony; Poland's Lower Silesia, and the Czech Republic's northern Bohemia.
4. Mediterranean basin (MB): air masses which mostly originated or passed over the Tyrrhenian and northern Mediterranean seas at altitudes below 3,000 $\mathrm{m}$ a.g.l. (32\%; possible pollution source Italy, southern France);

5. Eastern Europe (EE): air masses reaching CMP with north-easterly circulation, associated with very different air mass altitudes, ranging from below 1,000 to $5,000 \mathrm{~m}$ a.g.l. (12.4\%; pollution source areas Poland, Hungary, Czech Republic, Slovakia).

Analysis of the vertical back-trajectory motions (not reported here) showed that, apart from AO and WE circulations, mixing with lower tropospheric airmasses (possibly affected by anthropogenic emissions within the ABL) was likely for all the circulation classes.

For a systematic investigation of the possible relationship of air-mass circulations and $\mathrm{O}_{3}$ variability at $\mathrm{CMP}$, hourly $\mathrm{O}_{3}$ concentrations were analysed on the basis of the different air-mass clusters. Figure 8 reports the statistical distribution of the hourly $\mathrm{O}_{3}$ values at CMP: the distribution obtained is very well reproduced by a three-parameter Gaussian curve. By use of the statistical software Sigmaplot $\subset$ (Systat Software, http://www.sigmaplot.com), the non-linear regression was calculated, giving the following distribution values: $a=21.06 \pm 1.11, \quad b=4.56 \pm 0.28$, and $x_{0}=58.03 \pm 0.28 \mathrm{ppb}$, where:

$$
f(x)=a \exp \left(-0.5\left[\left(x-x_{0}\right) / b\right]^{2}\right)
$$

Figure $8 \mathrm{a}$ also reports the calculated fit with the interval (dashed lines) for the $95 \%$ confidence level. For each $\mathrm{O}_{3}$ value bin, we calculated the percentage of the air-mass cluster occurrence (Fig. 8b). As deduced by this analysis, the contribution of $\mathrm{MB}$ air-masses is maximized for $\mathrm{O}_{3}$ concentrations ranging from the lowest values to the distribution peak, whereas it decreased for $\mathrm{O}_{3}$ higher than 60 ppbv. On the other hand, the occurrence of $\mathrm{CE}$ and $\mathrm{EE}$ airmasses increased with increasing $\mathrm{O}_{3}$ values. In particular, the CE cluster is the atmospheric circulation prevailing (with $40 \%$ of occurrence) for $\mathrm{O}_{3}$ values between 65 and 70 ppbv. As shown in Fig. 8b, a generally low occurrence of AO circulation was observed for the different $\mathrm{O}_{3}$ values. Only the upper 

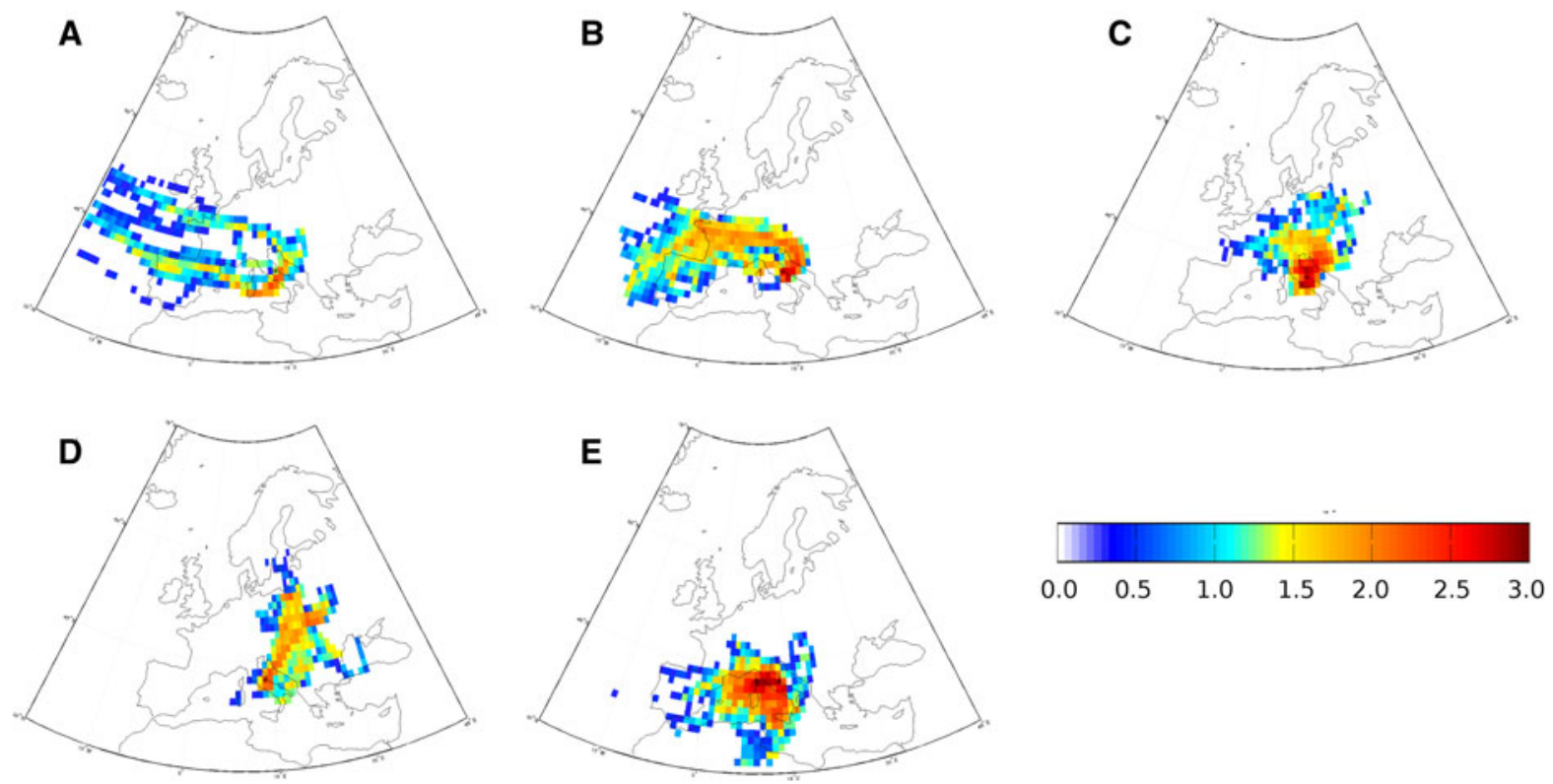

Figure 7

Field concentrations of back-trajectory points for the five air-mass clusters: Atlantic Ocean (a), western Europe (b), continental Europe (c), eastern Europe (d), Mediterranean basin (e). The coloured bar denotes the number of back-trajectory points on a logarithmic scale

$\mathrm{O}_{3}$ values observed at CMP were mostly associated with air-masses related with WE and AO circulations, suggesting that $\mathrm{O}_{3}$-enriched air masses from the free troposphere could significantly contribute to the episodic occurrence of these high $\mathrm{O}_{3}$ concentrations at the measurement site.

With the objective of studying the "baseline" atmospheric conditions (i.e. neglecting the effect of daytime thermal upward transport), the same analysis was repeated considering nighttime data only (00:00-06:00), which represent $34.5 \%$ of the whole data-set. Even if the population distribution of $\mathrm{O}_{3}$ values was characterised by the same modal peak $\left(x_{0}=58.73 \pm 0.37 \mathrm{ppb}\right)$, it appeared more peaked than for the all data selection (Fig. 8c), as also testified by the different fitting data of the Gaussian fit ( $a=25.36 \pm 2.37, b=3.47 \pm 0.37)$. This was mostly related to a higher relative occurrence of $\mathrm{O}_{3}$ values ranging from 55.0 to $62.5 \mathrm{ppb}$ and a lower relative occurrence of $\mathrm{O}_{3}$ values from 50.0 to 57.5 ppbv. It suggests that nighttime observations at CMP were more frequently affected by "baseline" atmospheric conditions with a lower relative contribution of low $\mathrm{O}_{3}$ episodes (possibly related to the diurnal upward transport of ABL air-masses depleted in $\mathrm{O}_{3}$ ). The distribution of air-mass occurrence for the different $\mathrm{O}_{3}$ values did not differ substantially from that when all the data were selected (Fig. 7d): MB air-mass circulation was tagged with low $\mathrm{O}_{3}$ concentrations ( $\sim 55 \mathrm{ppb}), \mathrm{CE}$ and $\mathrm{EE}$ circulations were frequently observed for the upper quartile of the $\mathrm{O}_{3}$ distribution, and the highest $\mathrm{O}_{3}$ concentrations $(>72$. $5 \mathrm{ppb}$ ) were related to the occurrence of $\mathrm{AO}$ and WE air masses.

\section{Comparison with Satellite Measurements}

Here, we present a comparison between the in-situ CMP $\mathrm{O}_{3}$ observations and tropospheric $\mathrm{O}_{3}$ retrievals (Fig. 9). For partial evaluation of possible uncertainties in TES spatial resolution and the aggregation algorithm, and, possibly, to provide an initial approximate evaluation of the representativeness of CMP measurements in respect of the "broad scale" spatial and temporal variability of $\mathrm{O}_{3}$ on a regional scale, we considered TES Daily Level 3 observations centred over the CMP location but with different spatial aggregations: $1^{\circ} \times 1^{\circ}$ and $3^{\circ} \times 3^{\circ}$. Moreover, we considered $\mathrm{O}_{3}$ mixing ratios at $681 \mathrm{hPa}$, which is 

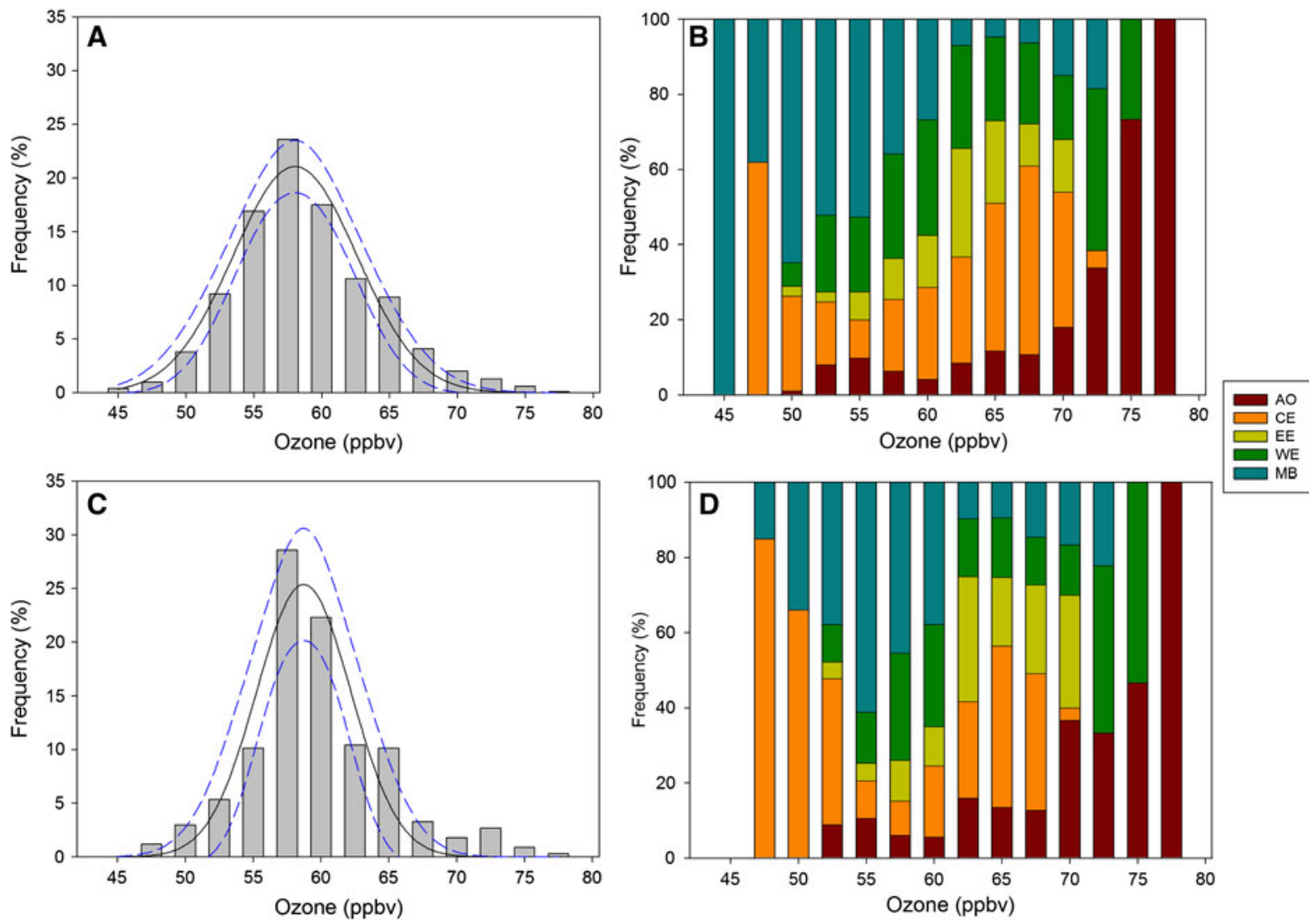

Figure 8

Statistical distribution of hourly $\mathrm{O}_{3}$ values at CMP during the field campaign for all data (a) and for nighttime (c). Gaussian fits (continuous line) with $95 \%$ confidence level (dashed lines) are also reported. Percentage contribution of air-mass circulation occurrence (AO Atlantic Ocean, $C E$ continental Europe, $E E$ eastern Europe, $W E$ western Europe, $M B$ Mediterranean basin) for each bin of the $\mathrm{O}_{3}$ values are reported on the right for all data (b) and for nighttime (d)

the TES layer which mostly approaches the CMP average pressure. The different TES data selections resulted in the same behaviour, with slowly decreasing $\mathrm{O}_{3}$ values from 4 to 16 August and two periods (centred around 20 and 26 August) characterised by enhanced values. On average, TES observations showed higher $\mathrm{O}_{3}$ values (ranging from $67.8 \pm 3.5$ to $68.5 \pm 4.9 \mathrm{ppbv}$ ) compared with the CMP observations (average values $60.5 \pm 4.5 \mathrm{ppbv}$ ), probably because of the well-known positive bias affecting tropospheric TES measurements (NASSAR et al., 2008). However, the satellite and in-situ time series reported significant similarities. In particular, the $\mathrm{O}_{3}$ increase around 20 August 2009 was captured both by in-situ and satellite measurements, when "free" tropospheric air masses affected CMP (discussed in the section "Tropospheric $\mathrm{O}_{3}$ Behaviour").
By contrast, significant differences were evident for 24 and 26 August, with CMP observations reporting decreasing $\mathrm{O}_{3}$ values not captured by satellite. The first period coincided with a sudden change in atmospheric conditions, with AO air masses replacing $\mathrm{EE}$ air masses in the night between 24 and 25 August. This was reflected by a dramatic decrease in $\mathrm{O}_{3}$ and $\mathrm{RH}$ at CMP. Thus, it is likely that TES observations were more affected by the high $\mathrm{O}_{3}$ concentrations observed on 24 August (discussed in the section "Tropospheric $\mathrm{O}_{3}$ Behaviour"). A similar explanation can be invoked to explain the differences observed on 26 August: relatively high $\mathrm{O}_{3}$ values were observed at CMP almost simultaneously with TES overpass (Fig. 3), probably because of the occurrence of significant thermal upward transport. It is therefore seen that, when local thermal processes or 


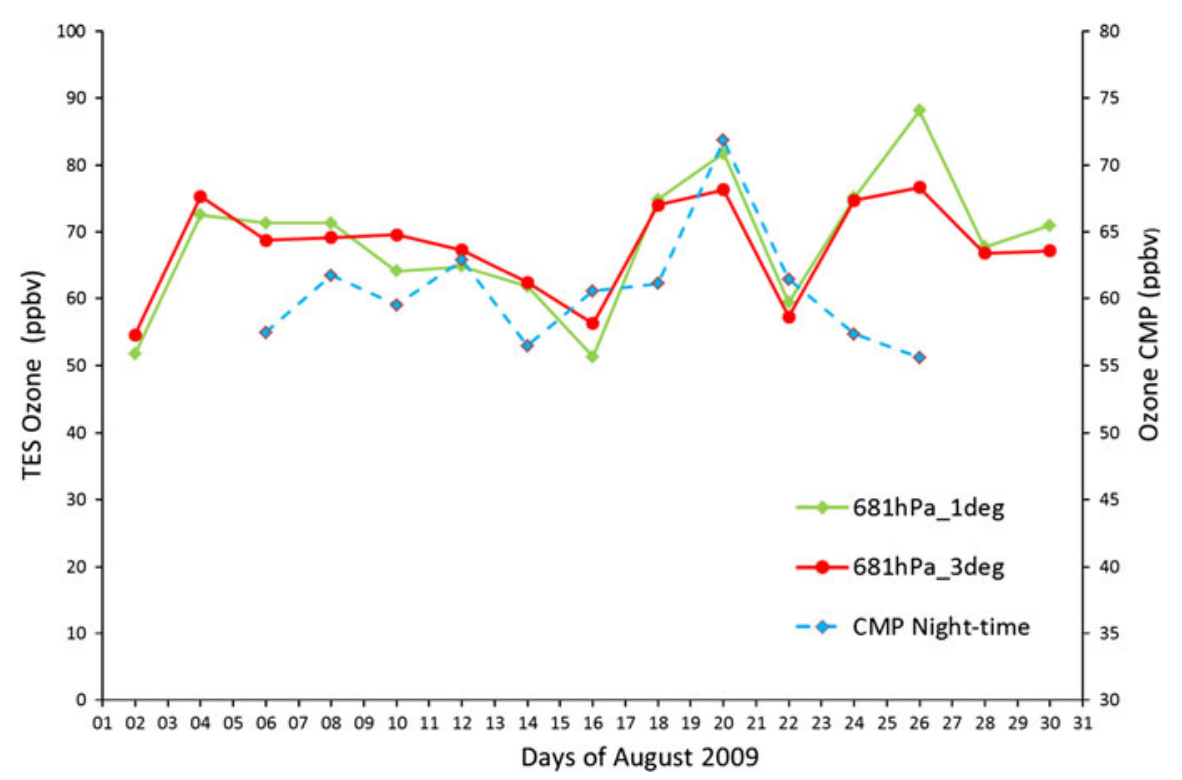

Figure 9

Daily TES ozone mixing ratio over the CMP region for the $681 \mathrm{hPa}$ layer and for different spatial aggregations $\left(1 \times 1^{\circ}\right.$ and $3 \times 3^{\circ}:$ green and red lines, respectively). For comparison, CMP daily $\mathrm{O}_{3}$ values obtained by averaging the hourly values for nighttime (from 0:00 to 5:00 $\mathrm{UTC}+1)$ are reported (blue line)

rapid synoptic changes are neglected during the field campaign period, the $\mathrm{O}_{3}$ measurements at $\mathrm{CMP}$ have similar variability in respect of satellite observations aggregated over relatively large spatial areas. Even this analysis is not conclusive for the issue at hand, although it suggests that the spatial representativeness of CMP data may exceed that of the local scale.

\section{Summary and Discussion}

An experimental campaign conducted at Campo Imperatore, Mt Portella, (CMP) during August 2009 has enabled preliminary evaluation of the summer background $\mathrm{O}_{3}$ variability at a high remote mountain site over central Italy. During the period considered, average $\mathrm{O}_{3}$ values were $60.0 \pm 5.1 \mathrm{ppb}$. As deduced from the analysis of average $\mathrm{O}_{3}$ values and diurnal and day-to-day $\mathrm{O}_{3}$ variability, the CMP observations were comparable with measurements at other European mountain stations. On a daily basis, surface $\mathrm{O}_{3}$ values seemed to be affected by mountain "thermal" wind, i.e. upslope flow during daytime and downslope flow during nighttime. Even if, on average, this daily wind variation led to the appearance of a small "reverse" $\mathrm{O}_{3}$ diurnal cycle (average amplitude
$5.0 \mathrm{ppb}$ ), polluted air masses richer in photochemical $\mathrm{O}_{3}$ could episodically affect the site, in association with upslope breezes.

Analysis of specific $\mathrm{O}_{3}$ episodes indicates that synoptic-scale transport processes contributed to $\mathrm{O}_{3}$ variability at CMP during the period investigated. To capture the main synoptic-scale flows occurring at the measurement site during the experimental campaigns, cluster analysis was applied to the HYSPLIT five-day back-trajectory ensembles calculated for CMP. This analysis led to identification of five principal circulation patterns affecting the site: continental Europe, CE (frequency of occurrence $23.0 \%$ ); western Europe, WE (24.2\%); eastern Europe, EE (12.4\%); Mediterranean basin, MB (32.0\%); and Atlantic Ocean, AO (8.4\%). Both for the "all-data" and "nighttime" data selection, the $\mathrm{MB}$ circulation (average $\mathrm{O}_{3} \quad 57.3 \pm 4.1$ and $59.1 \pm 3.9 \mathrm{ppb}$, respectively) prevail for the lowest range of observed $\mathrm{O}_{3}$ values, whereas the upper range of the distribution is mostly related to the $\mathrm{CE}$ (average $\mathrm{O}_{3} 60.6 \pm 5.3 \mathrm{ppb} ; 60.2 \pm 5.7 \mathrm{ppb}$ ) and $\mathrm{EE}$ (average $\mathrm{O}_{3} 61.8 \pm 3.8 \mathrm{ppb} ; 62.6 \pm 3.9 \mathrm{ppb}$ ) air masses. This suggests that atmospheric conditions connected with these circulation classes favoured the presence of high $\mathrm{O}_{3}$ values at CMP. The authors 
speculate that this could be because of the large anthropogenic emissions occurring in Europe and in northern/central Italy, and the meteorological conditions (i.e. anti-cyclonic conditions over Europe and the Mediterranean basin), which favour photochemical $\mathrm{O}_{3}$ production and enhance vertical transport of anthropogenic pollution on both continental and regional scales (Henne et al., 2005; Cristofanelli et al., 2009). Finally, it is observed that air masses from the free troposphere embedded within AO and WE circulations can favour the occurrence of specific high- $\mathrm{O}_{3}$ events.

Despite the relatively short time period, the analysis reported here shows that atmospheric observations at CMP can provide useful information enabling better characterisation of atmospheric variability in the Mediterranean region. Furthermore, we compared satellite-based observations of tropospheric $\mathrm{O}_{3}$ obtained by the NASA-TES instrument with in-situ CMP measurements. Despite a positive bias characterising TES measurements relative to CMP observations (ranging from 12 to $13 \%$, on average), the two time series had much similarity. All the above evidence indicates that the installation of a permanent facility for atmospheric composition observations at the CMP site could enable better investigation of the processes affecting the background troposphere of the Mediterranean basin. Being located more than $350 \mathrm{~km}$ south-east of the high mountain station of Mt Cimone, CMP can provide complementary information. For the field campaign period, the HYSPLIT back-trajectory analyses (not shown) showed that CMP was more affected by air masses from eastern Europe and the central Mediterranean basin than Mt Cimone, which was more affected by north-westerly air masses. Thus, this preliminary investigation suggests that a permanent station at CMP would be a very useful means of improving our knowledge of tropospheric variability in the Mediterranean basin (during the field campaign presented here, $32 \%$ of six-day back-trajectories originated in, and recirculated over, this region). Together with the Alpine stations and the Mt Cimone station in the northern Apennines, CMP could become part of a system of high-mountain stations extending through the Mediterranean basin.

\section{Acknowledgments}

This work was supported by the Ev-K2-CNR project SHARE (Stations at High Altitude for Research on the Environment) and the DTA-MIUR NextData Project. P. Di Carlo's work was supported by Fondazione CARISPAQ. The authors gratefully acknowledge the Rome section of the Italian CAI for hosting instruments in the Rifugio Duca deli Abruzzi. The authors also thank NOAA-ARL for providing the HYSPLIT model and NCEP GDAS meteorological input data on their website. The TES data used in this paper were produced with the Giovanni online data system, developed and maintained by the NASA GES DISC. We also acknowledge the TES mission scientists and associated JPL personnel for the production of the data used in this research. Ozone data for L'Aquila were provided by ARPA-Abruzzo via the on-line data base BRACE maintained by ISPRA (Istituto Superiore per la Protezione e la Ricerca Ambientale) at the web address http://www.brace. sinanet.apat.it. Finally, the authors are grateful to the three anonymous referees for their valuable suggestions.

Open Access This article is distributed under the terms of the Creative Commons Attribution License which permits any use, distribution, and reproduction in any medium, provided the original author(s) and the source are credited.

\section{REFERENCES}

Bonasoni, P., Stohl, A., Cristofanelli, P., Calzolari, F., Colomво,T., Evangelisti, F. (2000), Background ozone variations at Mt Cimone, Atmos. Environ. 34, 29-30.

Carnuth, W., Kempfer, U., and TrickL, T. (2002), Highlights of the tropospheric lidar studies at IFU within the TOR project, Tellus B $54,163-185$.

Chevalier, A., Gheusi, F., Delmas, R., Ordónez, C., Sarrat, C., Zbinden, R., Thouret, V., Athier, G., and Cousin, J-M. (2007), Influence of altitude on ozone levels and variability in the lower troposphere: a ground-based study for western Europe over the period 2001-2004, Atmos. Chem. Phys. 7, 4311-4326.

Cristofanelli, P. and Bonasoni, P. (2009), Background ozone in the southern Europe and Mediterranean area: influence of the transport processes, Environ. Poll. 157, 399-1406.

Cristofanelli, P., Marinoni, A., Arduini, J., Bonafè, U., Calzolari, F., Colombo, T., Decesari, S., Duchi, R., Facchini, M. C., Fierli, F., Finessi, E., Maione, M., Chiari, M., Calzolai, G., Messina, P., Orlandi, E., Roccato, F., and Bonasoni, P. (2009), Significant variations of trace gas composition and aerosol properties at Mt Cimone during air mass transport from North Africa-contributions from wildfire emissions and mineral dust, Atmos. Chem. Phys. 9, 4603-4619. 
Di Carlo, P., Pitari, G., Mancini, E., Gentile, S., Pichelli, E. and Viscontr G. (2007), Evolution of surface ozone in central Italy based on observations and statistical model, J. Geophys. Res. 112, D10316, doi:10.1029/2006JD007900.

Dorling, S.R., Davies, T.D., Pierce, C.E. (1992), Cluster analysis: A technique for estimating the synoptic meteorological controls on air and precipitation chemistry-Method and applications, Atmos. Environ. 26, 2575-2581.

Draxler, R.R., and Hess, G.D. (1998), An overview of the HYSPLIT_4 modeling system of trajectories, dispersion, and deposition, Aust. Meteor. Mag. 47, 295-308.

Duncan, B.N., Bey, I. (2004), A modeling study of the export pathways of pollution from Europe: seasonal and interannual variations (1987-1997), J. Geophys. Res. 109, D08301.

European Environment Agency (2009) Air pollution by ozone across Europe during summer, Technical report No 2/2010. (European Environment Agency, Copenaghen 2010)

Fischer, H., Kormann, R., KlüPfel, T., Gurk, C., Königstedt, R., Parchatka, U., Mühle, J., Rhee, T.S., Brenninkmeijer, C.A.M., Bonason, P. and Stohl, A. (2003), Ozone production and trace gas correlations during the June 2000 MINATROC intensive measurement campaign at Mt Cimone, Atmos. Chem. Phys. 3, 725-738.

Forster, P., Ramaswamy, V., Artaxo, P. et al.: Changes in Atmospheric Constituents and in Radiative Forcing, In Climate Change 2007: The Physical Science Basis. Contribution of Working Group I to the Fourth Assessment Report of the Intergovernmental Panel on Climate Change (eds. Solomon, S., Qin, D., Manning, M., Chen, Z., Marquis, M., Averyt, K.B., Tignor, M., Miller, H.L.) (Cambridge University Press, Cambridge, United Kingdom and New York, NY, USA, 2007).

Gheusi, F., Ravetta, F., Delbarre, H., Tsamalis, C., ChevalierRosso, A., Leroy, C., Augustin, P., Delmas, R., Ancellet, G., Athier, G., Bouchou, P., Campistron, B., Cousin, J.-M., FourMentin, M., MeYerfeld, Y. (2011), Pic 2005, a field campaign to investigate low-tropospheric ozone variability in the Pyrenees, Atmos. Res. 101, 640-665.

Henne, S., Dommen, J., Neininger, B., Reimann, S., Staehelin, J., and PRÉVôt, A. S. H. (2005), Influence of mountain venting in the Alps on the ozone chemistry of the lower free troposphere and the European pollution export, J. Geophys. Res. 110, D22307, doi: 10.1029/2005JD005936.

Henne, S., Solberg, S., Brunner, D., Folini, D., Klausen, J., Fleming, Z., and Buchmanns, B. (2008), Analysis of Ground Based Site Representativeness for European Scale Trend Analysis, GRA. 10, EGU2008-A-09402.

JACOBSON, M.Z., Atmospheric Pollution: history, science and regulation (Cambridge University Press, Cambridge, UK, 2002).

Klausen, J., Zellweger, C., Buchmann, B., Hofer, P. (2003), Uncertainty and bias of surface ozone measurements at selected Global Atmosphere Watch sites, J. Geophys. Res. 108 (D19), 4622, doi:10.1029/2003JD003710.

Kouvarakis, G., Vrekoussis, M., Mihalopoulos, N., Kourtidis, K., Rappenglueck, B., Gerasopoulos, E., Zerefos, C., 2002. Spatial and temporal variability of tropospheric ozone in the boundary layer above the Aegean Sea (eastern Mediterranean), J. Geophys. Res. 107 (D18), 8137, doi:10.1029/2000JD000081.
Lelieveld, J., Berresheim, H., Borrmann, S., Crutzen, P. J., Dentener, F. J., Fischer, H., Feichter, J., Flatau, P. J., Heland, J., Holzinger, R., Kormann, R., Lawrence, M. B., Levin, Z., Markowicz, K., Mihalopoulos, N., Minikin, A., Ramanthan, V., de Reus, M., Roelofs, G. J., Scheeren, H. A., Sciare, J., Schlager, H., Schulz, M., Siegmund, P., Steil, B., Stephanou, E. G., Stier, P., Traub, M., Warneke, C., Williams, J., and Ziereis, H. (2002), Global air pollution crossroads over the Mediterranean, Science 298, 794-799.

Lolis, C. J., Metaxas, D. A., and Bartzokas, A. (2008), On the intra-annual variability of atmospheric circulation in the Mediterranean region, Int. J. Climatol. 28: 1339-1355.

Monks, P.S., et al. (2009), Atmospheric composition change global and regional air quality, Atmos. Environ. 43, 5268-5350.

Mickley, L. J., JACoв D. J., Field B. D., and Rind D. (2004), Climate response to the increase in tropospheric ozone since preindustrial times: A comparison between ozone and equivalent $\mathrm{CO}_{2}$ forcings, J. Geophys. Res. 109, D05106, doi:1029/2003JD003653.

Nassar, R., Logan, J.A., Worden, H.M., et al. (2008), Validation of Tropospheric Emission Spectrometer (TES) nadir ozone profiles using ozonesonde measurements, J. Geophys. Res. 113, D15S17, doi:10.1029/2007JD008819.

Nolle, M., Ellul, R., Ventura, F., Güsten, H.A., 2005, Study of historical surface ozone measurements (1884-1900) on the island of Gozo in the central Mediterranean, Atmos. Environ. 39, 5608-5618.

Prèvôt, A.S.H., Dommen, J., BäUmle, M., Furger, M., (2000). Diurnal variations of volatile organic compounds and local circulation systems in an Alpine valley, Atmos. Environ. 34, 1413-1434.

Ribas, A., Peñuelas, J., 2004, Temporal patterns of surface ozone levels in different habitats of the North Western Mediterranean basin, Atmos. Environ. 38, 985-992.

Tarasova, O. A., Brenninkmeijer, C. A. M., Jöckel, P., ZvyaGintsev, A. M., and Kuznetsov, G. I. (2007), A climatology of surface ozone in the extra tropics: cluster analysis of observations and model results, Atmos. Chem. Phys. 7, 6099-6117, doi: 10.5194/acp-7-6099-2007.

UNEP and WMO (2011), Integrated Assessment of Black Carbon and Tropospheric Ozone, Bart Ullstein (Ed.), Banson, UK.

Vautard R., Honoré C., Beekmann M., Rouil L. (2005), Simulation of ozone during the August 2003 heat wave and emission control scenarios, Atmos. Environ. 39, 2957-2967.

West J. J., Naik V., Horowitz L. W., and Fiore A. M. (2009), Effect of regional precursor emission controls on long-range ozone transport - Part 2: Steady-state changes in ozone airquality and impacts on human mortality, Atmos. Chem. Phys. 9, 6095-6107, doi:10.5194/acp-9-6095-2009.

Worden, H. M., Logan, J.A., Worden, J.R., et al. (2007), Comparisons of Tropospheric Emission Spectrometer (TES) ozone profiles to ozonesondes: Methods and initial results, J. Geophys. Res. 112, D03309, doi:10.1029/2006JD007258.

Zellweger, C., Ammann, M., Buchmann, B., Hofer, P., Lugauer, M., Ruettimann, R., Streit, N., Weingartner, E., and BaltenSPERGER, U. (2000), Summertime NOy speciation at the Jungfraujoch, $3580 \mathrm{~m}$ above sea level, Switzerland, J. Geophys. Res. 105(D5), 6655-6667. 